\title{
Uji Potensi Isolat Khamir Dari Rhizosfer Mangrove Wonorejo dan Gunung Anyar Sebagai Agen Penghasil IAA (Indole Acetic Acid)
}

\author{
Faifta Nandika Maya dan Nur Hidayatul Alami \\ Departemen Biologi, Fakultas Sains, Institut Teknologi Sepuluh Nopember (ITS) \\ e-mail: hidayatulalami@bio.its.ac.id
}

\begin{abstract}
Abstrak-Indole-3-acetic acid (IAA) merupakan salah satu fitohormon golongan auksin alami yang disintesis dari triptofan yang berfungsi dalam pertumbuhan dan perkembangan tanaman. Khamir merupakan salah satu mikroorganisme rhizosfer yang mampu mensintesis IAA. Penelitian ini dilakukan untuk mengetahui kemampuan isolat khamir yang berasal dari rhizosfer mangrove dalam menghasilkan IAA serta pengaruh lama waktu inkubasi terhadap konsentrasi IAA dan berat kering sel yang dihasilkan. Metode yang digunakan meliputi uji kualitatif dengan mengamati perubahan warna yangg terjadi serta seacara kuantitatif dengan mengukur absorbansi warna yang dihasilkan menggunakan spektrofotometer. Hasil yang diperoleh yaitu semua isolat yang digunakan memiliki potensi dalam menghasilkan IAA, dimana isolat G8.1 memiliki kemampuan tertinggi dalam menghasilkan IAA sebsar 11,97 ppm. Lama waktu inkubasi ternyata berpengaruh terhadap konsetrasi IAA dan berat kering sel yang dihasilkan. Konsentrasi IAA paling tinggi dihasilkan pada hari ke tujuh $(168 \mathrm{~h})$ sebesar $43,50 \mathrm{ppm}$ dengan berat kering sel 0,119 gram.
\end{abstract}

Kata Kunci_IAA, Khamir, Waktu Inkubasi, Berat Kering Sel.

\section{PENDAHULUAN}

I NDOLE-3-ACETIC ACID (IAA) merupakan salah satu fitohormon golongan auksin alami yang memiliki peran penting dalam pertumbuhan dan perkembangan tanaman [1]. Beberapa peran penting yang dipengaruhi oleh kerja IAA antara lain, pembesaran sel, pembelahan sel, differensiasi jaringan pengangkut, inisiasi akar, respon tropistik (pembengkokan), dominansi apikal, pertumbuhan buah, pematangan buah, pembungaan, pertumbuhan bagian-bagian bunga dan menginduksi terbentuknya bunga betina pada jenis bunga dioecious (bunga berumah dua) [2]. IAA juga dapat meningkatkan sintesis DNA dan RNA dengan cara meningkatkan aktivitas transkripsi DNA untuk membentuk template atau dengan mempengaruhi efektifitas RNA Polimerase [3].

Produksi hormon endogen seperti IAA pada tanaman sangat rendah [4]. Keterbatasan kemampuan tanaman dalam mensintesis IAA menyebabkan tanaman memenuhi kebutuhan akan hormon dengan bantuan dari mikroorganisme. Salah satu mikroorgasnisme memiliki potensi untuk menghasilkan IAA yaitu yeast atau khamir.

Hasil penelitian sebelumnya, telah didapatkan beberapa isolat khamir yang diisolasi dari rhizosfer mangrove Gunung Anyar dan Wonorejo diketahui berpotensi dalam mendegradasi selulosa, protein, lemak, serta mampu melarutkan fosfat [5]. Akan tetapi, isolat-isolat tersebut belum diketahui kemampuannya dalam menghasilkan IAA. Oleh karena itu, dilakukannya penelitian ini bertujuan untuk mengetahui kemampuan koleksi isolat khamir di Laboratorium Mikrobiologi dan Bioteknologi ITS untuk menghasilkan IAA, serta pengaruh masa inkubasi terhadap konsentrasi IAA dan berat kering sel yang dihasilkan.

\section{METODOLOGI}

\section{A. Waktu dan Tempat Penelitian}

Penelitian ini dilaksanakan di Laboratorium Mikrobiologi dan Bioteknologi Departemen Biologi Fakultas Sains, Institut Teknologi Sepuluh Nopember, Surabaya, Provinsi Jawa Timur pada bulan September 2018 - Januari 2019.

\section{B. Peremajaan Isolat Khamir}

Kultur masing-masing koleksi isolat khamir diambil 1 ose dan diinokulasikan ke medium YMEA. Kultur dinkubasi selama 24-48 jam dalam suhu ruang. Tujuan penginokulasian isolat ke medium YMEA adalah untuk meremajakan isolat supaya isolat menjadi aktif kembali. Keberhasilan peremajaan isolat ditandai dengan tumbuhnya isolat pada medium YMEA.

\section{Pembuatan Kurva Standart IAA}

Pertama, dibuat larutan stok dengan konsentrasi $100 \mu \mathrm{g} / \mathrm{ml}$ (100 ppm) dengan melarutkan 0,01 gram IAA dalam $100 \mathrm{ml}$ akuades. Larutan stok ini kemudian diencerkan dengan pengenceran untuk membuat larutan IAA standart dengan konsentrasi 10, 9, 8, 7, 6, 5, 4, 3, 2, 1 dan 0 ppm. Selanjutnya, disiapkan 11 tabung reaksi. Masing-masing tabung ditambahkan dengan $2 \mathrm{ml}$ reagen Salkowski dan $1 \mathrm{ml}$ larutan standart $(10,9,8,7,6,5,4,3,2,1$ dan 0 ppm). Setelah itu, tabung - tabung reaksi tersebut didiamkan selama 30 menit pada ruangan gelap [6]. Kemudian, setelah terjadi perubahan warna pada larutan menjadi pink atau merah, intensitas perkembangan warna diukur dengan spektrofotometer pada panjang gelombang $530 \mathrm{~nm}\left(\mathrm{OD}_{530}\right)$ [7]. Absorbansi tiap larutan standart dicatat. Data tersebut kemudian akan digunakan sebagai pembuatan kurva standart IAA.

\section{Pembuatan Starter Khamir}

Masing-masing isolat diinokulasikan sebanyak 3 ose penuh ke dalam botol kaca yang telah berisi medium YMB sebanyak $50 \mathrm{ml}$. Kultur diinkubasi dalam shaker dengan kecepatan 130 rpm pada suhu $26^{\circ} \mathrm{C}$ atau suhu ruang selama 48 jam. 
Tabel 1.

Hasil Uji Kualitatif Isolat Khamir dalam Menghasilkan IAA.

\begin{tabular}{ccc}
\hline \hline No & Kode Isolat & Reaksi Warna \\
\hline 1 & W5.1 & + \\
2 & W7.3 & + \\
3 & G8.1 & + \\
4 & G4.1 & + \\
5 & G10.1 & + \\
6 & G3.3 & + \\
\hline \hline$+:$ ada perubahan warna (potensi menghasilkan IAA),
\end{tabular}

Keterangan: +: ada perubahan warna (potensi menghasilkan IAA), -: tidak ada perubahan warna (tidak berpotensi menghasilkan IAA).

Selanjutnya, kultur cair tersebut diamati pertumbuhannya hingga mencapai OD600 nm = 0,6 [6] (kepadatan sekitar 107 $\mathrm{sel} / \mathrm{ml})$.

\section{E. Uji Kualitatif dan Kuantitatif Isolat Khamir}

Sebanyak 12 botol kaca ukuran $150 \mathrm{ml}$ diisi dengan $50 \mathrm{ml}$ medium YMB yang telah ditambah dengan L-tryptophan 200 ppm $(200 \mu \mathrm{g} / \mathrm{ml})$. Selanjutnya, sebanyak 10\% starter dari 6 isolat yeast yang terpilih diambil dan diinokulasi ke dalam medium YMB yang telah diberi L-tryptophan. Kemudian, kultur diinkubasi dalam shaker dengan kecepatan $130 \mathrm{rpm}$ pada suhu $26^{\circ} \mathrm{C}$ atau suhu ruang selama 48 jam dengan ditutup aluminium foil. Setelah inkubasi selesai, kultur diambil sebanyak $5 \mathrm{ml}$ dan disentrifugasi $8000 \mathrm{rpm}$ selama 10 menit lalu supernatan diambil. Selanjutnya, $1 \mathrm{ml}$ supernatan dicampur dengan $2 \mathrm{ml}$ reagen Salkowski. Campuran tersebut kemudian didiamkan selama 30 menit dalam ruangan gelap. Uji kualitatif dilakukan dengan mengamati adanya perubahan warna larutan menjadi pink hingga merah. Sedangkan, uji kuantitatif dilakukan dengan mengukur intensitas perubahan warna dengan spektrofotometer pada panjang gelombang 530 $\mathrm{nm}\left(\mathrm{OD}_{530}\right)$ [7].

\section{F. Pengaruh Lama Waktu Inkubasi terhadap Produksi IAA dan Massa Sel yang Dihasilkan}

Sebanyak 3 botol kaca ukuran $500 \mathrm{ml}$ diisi dengan $100 \mathrm{ml}$ medium YMB yang telah ditambah dengan L-tryptophan 200 ppm $(200 \mu \mathrm{g} / \mathrm{ml})$. Selanjutnya, sebanyak $10 \%$ starter dari isolat yeast yang terbaik, diinokulasi ke dalam medium YMB yang telah diberi L-tryptophan. Kemudian, kultur diinkubasi dalam shaker dengan kecepatan $130 \mathrm{rpm}$ pada suhu $26^{\circ} \mathrm{C}$ atau suhu ruang dengan ditutup aluminium foil. Lama waktu inkubasi berlangsung dari 24-168 jam (7 hari) dan konsentrasi IAA yang dihasilkan diukur setiap 24 jam. Setelah inkubasi selesai, kultur diambil sebanyak $5 \mathrm{ml}$ dan disentrifugasi 8000 rpm selama 10 menit lalu supernatan diambil. Selanjutnya, 1 $\mathrm{ml}$ supernatan dicampur dengan $2 \mathrm{ml}$ reagen Salkowski. Isolat diamati dan diukur konsentrasi IAA yang dihasilkan.

Dari hasil sentrifugasi kultur, selain supernatan juga terdapat pelet (endapan) yang akan ditimbang berat keringnya. Hal ini bertujuan untuk mengetahui jumlah berat kering sel. Pertama, pelet dalam tabung sentrifugasi diberi sedikit akuades, kemudian tabung sedikit digoyang agar pelet yang mengendap pada bagian dasar tabung dapat tercampur. Kemudian, pelet dituangkan di atas kertas saring Whatman dan dioven dengan suhu $90^{\circ} \mathrm{C}$ selama 24 jam [8]. Sebelumnya, kertas saring tanpa pelet dioven dengan suhu $90^{\circ} \mathrm{C}$ dan ditimbang beratnya. Berat kering sel merupakan selisih antara

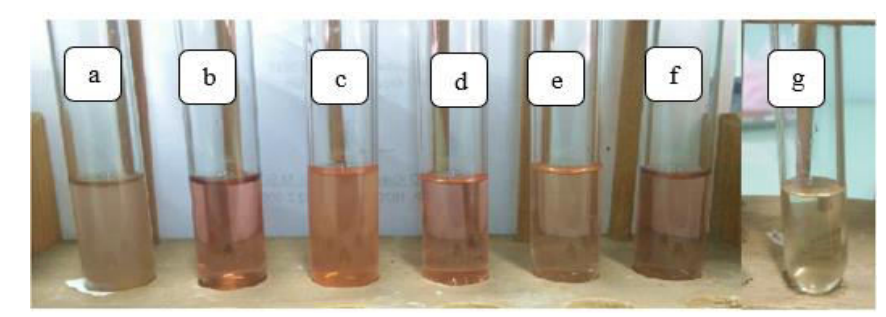

Gambar 1. Reaksi Perubahan Warna Isolat Setelah Diberi Reagen Salkowski

Keterangan : (a) W5.1, (b) W7.3, (c) G8.1, (d) G4.1, (e) G10.1, (f) G3.3, (g) Medium Kontrol (YMB+Reagen Salkowski)

berat kertas saring dengan pelet setelah dioven dengan berat kertas saring tanpa pelet setelah dioven.

\section{HASIL DAN PEMBAHASAN}

\section{A. Hasil Uji Kualitatif dan Kuantitatif Isolat Khamir dalam Menghasilkan IAA}

Kemampuan isolat-isolat khamir dalam menghasilkan IAA diuji secara kualitatif dan kuantitatif. Uji secara kualitatif dilakukan dengan menggunakan reagen Salkowski yang diteteskan pada supernatan yang dihasilkan setelah disentrifugasi. Hasil positif uji kualitatif dicirikan dengan berubahnya warna larutan menjadi merah atau merah muda setelah diberi reagen Salkowski [9]. Hasil uji kualitatif isolat khamir dalam menghasilkan IAA dapat dilihat pada Tabel 1 dan reaksi warna pada masing-masing isolat pada Gambar 1.

Dari Tabel 1 dan Gambar 1, dapat dilihat bahwa semua isolat khamir yang digunakan memiliki potensi dalam menghasilkan IAA. Hampir 80\% mikroorgnisme rhizosfer mampu menghasilkan IAA [10]. Semua isolat menunjukkan hasil positif terhadap uji kualitatif yang ditunjukkan dengan kemampuannya dalam menghasilkan warna merah dengan intensitas kepekatan warna yang berbeda-beda. Warna merah terbentuk karena adanya interaksi antara IAA dengan ion $\mathrm{Fe}^{3+}$ dalam reagen Salkowski membentuk kompleks tris (indole-3aceto) iron (III) $\mathrm{Fe}\left[\left(\mathrm{C}_{8} \mathrm{H}_{6} \mathrm{~N}\right) \mathrm{CH} 2 \mathrm{COO}\right]_{3}$ melalui reaksi kompleks dan reaksi redoks [11]. Warna merah yang semakin pekat menunjukkan kandungan IAA yang dihasilkan semakin tinggi [9].

Isolat khamir yang mampu menghasilkan warna merah pada uji kualitatif, akan dilanjutkan dengan uji kuantitatif. Uji kuantitatif dilakukan dengan mengukur intensitas perubahan warna dengan spektrofotometer pada panjang gelombang 530 $\mathrm{nm}\left(\mathrm{OD}_{530}\right)$ [7]. Nilai konsentrasi IAA dihitung dengan persamaan garis yang diperoleh dari kurva standar (Gambar 2), dimana sumbu $X$ menyatakan konsentrasi IAA dan sumbu Y menyatakan nilai absorbansi [12]. Nilai konsentrasi IAA yang dihasilkan tiap isolat dapat dilihat pada Gambar 3.

Dari Gambar 2 dan 3, terlihat bahwa setiap khamir memiliki kemampuan yang berbeda dalam menghasilkan IAA. Isolat khamir yang menghasilkan IAA paling tinggi selama inkubasi 48 jam yaitu G8.1 sebesar 11,97 ppm dan yang paling rendah W5.1 sebesar 3,56 ppm. Hal ini dipengaruhi oleh sifat fisiologis masing-masing khamir dalam mengkonversi triptofan menjadi IAA [13]. Akan tetapi, dalam penelitian ini tidak dilakukan identifikasi terhadap isolat khamir yang digunakan, sehingga tidak diketahui genusnya. 


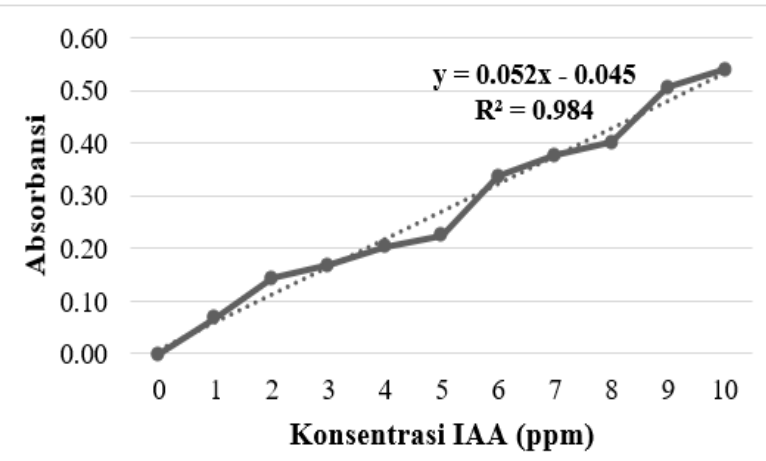

Gambar 2. Kurva Standart IAA.

Prekursor utama dalam biosintesis IAA adalah triptofan. Oleh sebab itu, fungsi penambahan L-triptofan sebesar 200 ppm pada medium kultur adalah agar IAA dapat dihasilkan. Pada penelitian yang dilakukan oleh [14] menggunakan Saccharomyces cerevisae, didapatkan 3 gen utama yang berperan terhadap biosintesis IAA pada khamir. Ketiga gen tersebut yaitu ALD2 (Aldehid dehidrogenase), ARO9 (Aromatik transminase) dan $A D H 2$ (Alkohol dehidrogenase). $A L D 2$ berfungsi mengoksidasi indol asetaldehid menjadi IAA, ARO9 berfungsi untuk mengkonversi triptofan menjadi indol piruvat dan $A D H 2$ berfungsi untuk mengkonversi indol asetaldehid (IAD) menjadi menjadi indol-3-etanol [14]. Isolat G8.1 memiliki kemampuan tertinggi dalam menghasilkan IAA kemungkinan berkaitan dengan aktivitas ketiga gen tersebut.

Terdapat 6 jalur biosintesis IAA yang melibatkan triptofan secara langsung sebagai prekursor utama. Berdasarkan penelitian yang telah dilakukan, jalur IPA (Indole Pyruvic Acid) merupakan jalur yang umum digunakan oleh khamir dalam menghasilkan IAA [15]. Tingginya konsentrasi IAA yang dihasilkan oleh isolat G8.1 dapat disebakan karena isolat tersebut mampu memproduksi IAA melalui lebih dari satu jalur sehingga proses pembentukan IAA berlangsung lebih efektif dan jumlah IAA yang dihasilkan jauh lebih tinggi. Sedangkan konsentrasi IAA terendah dihasilkan oleh isolat W5.1, dimana kemungkinan isolat tersebut hanya mampu menjalankan satu jalur saja sehingga IAA yang dihasilkan lebih sedikit.

IAA pada beberapa jenis khamir berfungsi untuk membentuk filamen yang berguna untuk invasi serta pemanjangan hifa/pseudohifa untuk memperluas daerah penyerapan nutrisi [16]. Contohnya pada Saccharomyces cerevisae, IAA berfungsi sebagai sinyal untuk mengatur filamentasi yang berfungsi untuk invasi. Sedangkan pada kebanyakan khamir patogen seperti Candida albicans, IAA berfungsi untuk menginduksi pembentukan hifa dan transisi dimorfik [13].

Beberapa faktor lain yang juga dapat mempengaruhi biosintesis IAA pada khamir yaitu nilai $\mathrm{pH}$ pada substrat/medium, suhu, penggunaan sumber karbon dan nitrogen serta ketersediaan triptofan pada medium. Selain itu, khamir kelompok Ascomycetes mampu menghasilkan IAA lebih tinggi dibandingkan dengan kelompok Basidiomycetes [17]. Pada penelitian yang dilakukan oleh Sun, dengan mengisolasi khamir dari filosfer tanaman Drosera indica, didapatkan hasil bahwa secara umum, khamir mampu

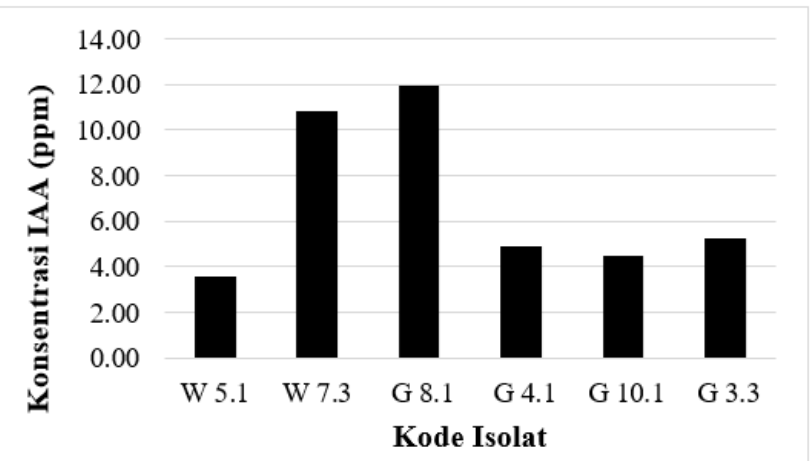

Gambar 3. Konsentrasi IAA yang Dihasilkan oleh Isolat Khamir.

menghasilkan IAA pada kondisi lingkungan yang asam atau netral, bukan pada kondisi alkalin. Selain itu, konsentrasi IAA yang tinggi dapat dihasilkan pada suhu $28^{\circ} \mathrm{C}$ yang dibandingkan dengan suhu $37^{\circ} \mathrm{C}$ dan $16^{\circ} \mathrm{C}$ [18].

\section{A. Pengaruh Lama Waktu Inkubasi terhadap Produksi IAA dan Massa Sel yang Dihasilkan}

Isolat khamir yang menghasilkan konsentrasi IAA paling tinggi yaitu isolat G8.1 dipilih untuk uji lebih lanjut dengan memanipulasi lama waktu inkubasi selama 7 hari dan dihitung konsentrasi serta berat kering sel perharinya. Besar konsentrasi IAA yang dihasilkan dan berat kering sel selama 7 hari dapat dilihat pada Gambar 4.

Dari Gambar 4 dapat dilihat bahwa terdapat peningkatan pada berat kering sel dan konsentrasi IAA yang dihasilkan sampai hari ke-4. Sel khamir mulai memproduksi IAA pada hari pertama atau setelah diinkubasi 24 jam. Pada hari ke-5, pertambahan berat kering sel terlihat stagnan atau pertambahannya sangat sedikit sekali yang dapat dilihat dari grafik yang berbetuk mendatar (Gambar 4) dan kembali meningkat sampai hari ke-7.

Konsentrasi IAA akan meningkat seiring dengan umur kultur sel mikroorganisme hingga mencapai fase stasioner [19]. Jadi, konsentrasi IAA akan terus meningkat sampai sel memasuki fase stasioner, hal ini terlihat pada hari ke-4 dan ke5 (Gambar 4), dimana berat kering sel mengalami peningkatan yang sedikit sekali dan garis pada grafik terlihat datar, tetapi terjadi peningkatan paling tinggi terhadap konsentrasi IAA yang dihasilkan. Sehingga, ada kemungkinan pada hari ke-4 dan ke-5, sel telah memasuki fase stasioner. Peningkatan produksi IAA pada fase stasioner pada khamir berhubungan dengan menurunnya sumber karbon untuk memenuhi kebutuhan nutrisi bagi metabolisme sel [16].

Pada hari ke-6 dan ke-7 (Gambar 4) berat kering sel terus bertambah diikuti dengan meningkatnya konsentrasi IAA. Dalam pengukuran berat kering sel, tidak dapat dibedakan antara sel yang hidup dan yang mati, sehingga tidak dapat dijadikan acuan apakah berat sel yang bertambah berasal dari pertumbuhan jumlah sel yang hidup. Sel yang mati juga dapat terakumulasi saat perhitungan berat kering, sehingga menyebabkan peningkatan berat sel kering. Selain itu, saat kekurangan energi atau mulai memasuki fase stasioner, sel khamir akan melakukan adaptasi dengan cara membentuk filamen. Dari penelitian yang telah dilakukan oleh [20] menggunakan Saccharomyces cerevisae, sel yang memasuki 


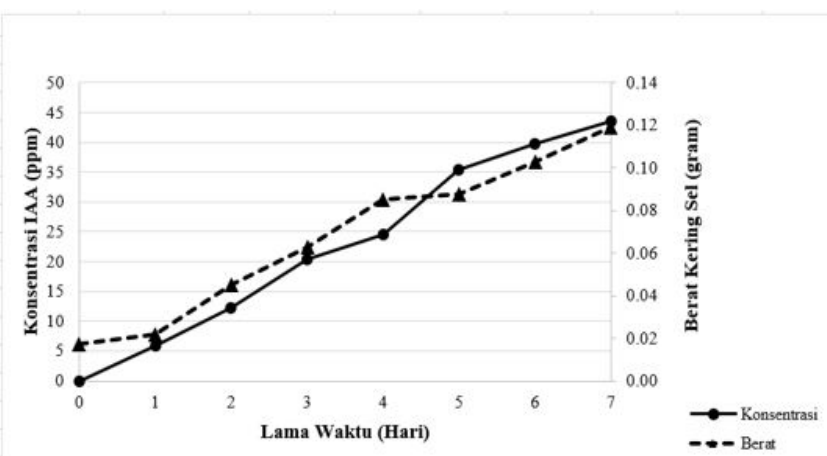

Gambar 4. Konsentrasi IAA dan Berat Kering Sel Khamir Isolat G.81 Selama Tujuh Hari.

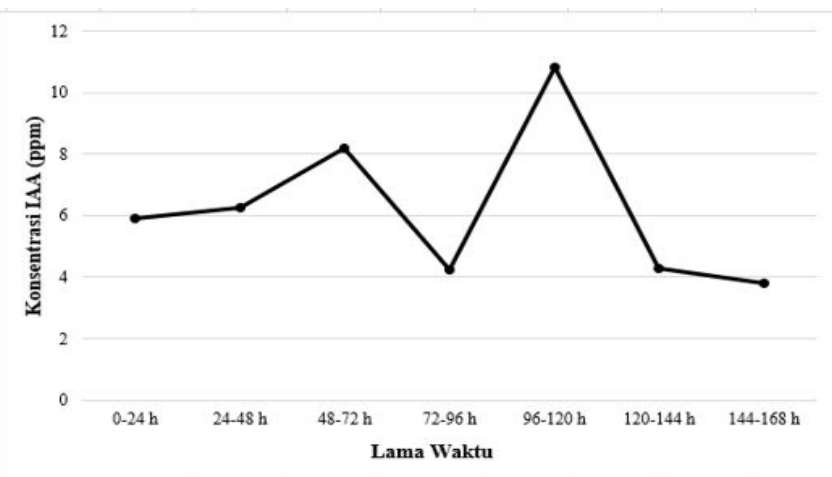

Gambar 5. Grafik Pertambahan Konsentrasi IAA Selama 7 Hari.

fase stasioner akan menampakkan filamen yang "lebih nyata" [20]. Adanya pertambahan berat kering sel pada hari ke-6 dan ke-7, kemungkinan dapat berasal dari filamen-filamen yang dibentuk oleh sel khamir, dimana salah satu fungsi IAA bagi khamir yaitu untuk menginduksi filamentasi.

IAA pada konsentrasi tinggi dapat meningkatkan produksi filamen. Pada saat konsentrasi IAA diluar sel tinggi, faktor transkripsi Yapl akan berpindah ke nukleus dan menginduksi pembentukan protein-Avt yang menyebabkan peningkatan IAA yang ditransfer ke dalam sel, kemudian protein permukaan sel FLOII akan meningkatkan produksi filamen, begitu juga sebaliknya [21]. Bagian dari IAA yang digunakan saat pembentukan filamen, kemungkinan terletak pada gugus karboksil (RCOOH). Hal ini karena, salah satu protein pembentuk filamen mengandung gugus karboksil, yaitu Acclp (Acetyl-CoA carboxylase) yang mampu membentuk filamen berukuran besar [22].

Dari Gambar 5 dan 6 terlihat bahwa pada hari ke-2 menuju ke-3 (48-72 h) sampai hari terakhir (144-168 h), ketika pertambahan berat kering menurun, maka pertambahan konsentrasi IAA meningkat, begitu juga sebaliknya. Dari pola tersebut, terdapat kemungkinan bahwa konsentrasi IAA yang tinggi mampu menghambat pertumbuhan sel. Menurut [18], pada filum Ascomycota, IAA pada konsentrasi tinggi (1250$5000 \mu \mathrm{M}$ ) dapat menghambat pertumbuhan sel khamir dan menginduksi fiamentasi, tetapi pada konsentrasi rendah (312,5-625 $\mu \mathrm{M})$ tidak berefek atau dapat meningkatkan pertumbuhan sel khamir, sedangkan pada filum Basidiomycota, spesies yang berbeda atau strain yang berbeda pada spesies yang sama, menunjukkan respon berbeda terhadap konsentrasi optimal IAA yang dibutuhkan untuk

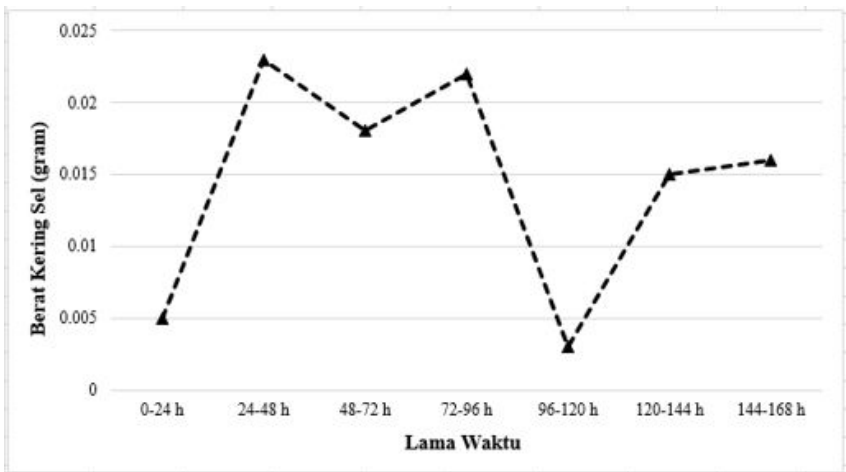

Gambar 6. Grafik Pertambahan Berat Kering Sel Selama 7 Hari.

Tabel 2.

Hasil Uji Duncan Antara Lama Waktu Inkubasi dengan Konsentrasi IAA dan Berat Sel Kering

\begin{tabular}{ccc}
\hline \hline Lama Waktu (Jam) & $\begin{array}{c}\text { Konsentrasi } \\
\text { IAA (ppm) }\end{array}$ & $\begin{array}{c}\text { Berat Kering } \\
\text { Sel (gram) }\end{array}$ \\
\hline $0 \mathrm{~h}$ & $0,000^{\mathrm{a}}$ & $0,017^{\mathrm{a}}$ \\
$24 \mathrm{~h}$ & $5,89^{\mathrm{b}}$ & $0.022^{\mathrm{b}}$ \\
$48 \mathrm{~h}$ & $12,14^{\mathrm{c}}$ & $0.045^{\mathrm{c}}$ \\
$72 \mathrm{~h}$ & $20,35^{\mathrm{d}}$ & $0.063^{\mathrm{d}}$ \\
$96 \mathrm{~h}$ & $24,60^{\mathrm{e}}$ & $0,085^{\mathrm{e}}$ \\
$120 \mathrm{~h}$ & $35,41^{\mathrm{f}}$ & $0.088^{\mathrm{f}}$ \\
$144 \mathrm{~h}$ & $39,71^{\mathrm{g}}$ & $0,103^{\mathrm{g}}$ \\
$168 \mathrm{~h}$ & $43,50^{\mathrm{h}}$ & $0,119^{\mathrm{h}}$ \\
\hline \hline
\end{tabular}

Keterangan: Angka yang diikuti oleh huruf yang berbeda menunjukkan perbedaan yang signifikan berdasarkan Uji Duncan pada taraf kepercayaan $95 \%(\alpha=0,05)$

menghambat atau meningkatkan pertumbuhan selnya. Pengaruh konsentrasi IAA terhadap pertumbuhan sel juga dipengaruhi oleh spesies atau bahkan strain dari isolat khamir tersebut. Selain itu, pada hari ke-4 menuju hari ke-5 (96-120h), pertambahan berat kering hanya sebesar 0,03 gram. Akan tetapi, pertambahan konsentrasi IAA yang dihasilkan (Gambar 5) menunjukkan peningkatan yang paling tinggi (96-120h), yaitu sebesar 10,81 ppm. Kemungkinan, pada jangka waktu tersebut, sel telah memasuki fase stasioner yang menyebabkan peningkatan produksi IAA [19].

Selain analisis secara deskriptif, dilakukan juga analisis secara statistik dengan uji ANOVA-One Way. Hasil uji ANOVA-One Way diperoleh nilai $p$-value $<0,05$, sehingga dapat disimpulkan terdapat perbedaan antar perlakuan, yaitu lama waktu inkubasi dengan konsentrasi IAA yang dihasilkan dan berat kering sel. Karena terdapat perbedaan pada hasil uji ANOVA-One Way, maka dilakukan uji lanjutan menggunakan uji Duncan. Hasil dari uji Duncan dapat dilihat pada Tabel 2.

Dari Tabel 2, terlihat bahwa terdapat perbedaan yang signifikan antara lama waktu inkubasi dengan konsentrasi IAA yang dihasilkan dan berat kering sel. Selain itu, dari hasil regresi juga diperoleh nilai $\mathrm{R}^{2}$ pada konsentrasi IAA sebesar 0,991 dan pada berat kering sel sebesar 0,981. Sehingga dapat dikatakan bahwa baik konsentrasi IAA dan berat kering sel mengalami peningkatan. Semakin lama waktu inkubasi, semakin tinggi dan besar konsentrasi IAA serta berat kering sel yang dihasilkan. Berat kering sel tidak menjadi acuan untuk menentukan pertumbuhan sel, karena di dalam berat kering sel selain sel yang hidup, terdapat pula sel yang sudah mati dan juga filamen-filamen yang dibentuk sehingga mempengaruhi berat yang dihitung. Konsentrasi IAA paling tinggi dihasilkan 
pada waktu inkubasi hari ketujuh (168h) sebesar 43,50 ppm dengan berat kering sel 0,119 gram.

\section{KESIMPULAN}

Semua isolat khamir yang berasal dari rhizosfer mangrove Wonorejo dan Gunung Anyar mampu menghasilkan IAA. Isolat yang menghasilkan IAA paling tinggi adalah isolat G8.1 sebesar 11,97 ppm. Lama waktu inkubasi berpengaruh terhadap konsentrasi IAA dan berat kering sel yang dihasilkan. Semakin lama waktu inkubasi, konsentrasi IAA dan berat kering sel yang dihasilkan semakin tinggi. Konsentrasi IAA paling tinggi dihasilkan pada waktu inkubasi hari ketujuh (168h) sebesar 43,50 ppm dengan berat kering sel 0,119 gram.

\section{DAFTAR PUSTAKA}

[1] B. Kukavica, A. Mitrovic, M. Mojovic, and S. V. Jovanovic, "Effect of indole-3-acetic acid on Pea Root Growth, Peroxidase Profiles and Hydroxyl Radical Formation," Arc.Biol.Sci, vol. 59, no. 4, pp. 319-326, 2007.

[2] P. Davies, Plant Hormones: Biosynthesis, Signal Transduction, Action, Revised Th. USA: Springer, 2007.

[3] I. Kresnawaty, S. Andanawarih, Suharyanto, and Tri-Panji, "Optimisasi dan pemurnian IAA yang dihasilkan Rhizobium sp. dalam medium serum lateks dengan suplementasi triptofan dari pupuk kandang," Menara Perkeb., vol. 76, no. 2, pp. 74-82, 2008.

[4] K. Ljung et al., "Sites and regulation of auxin biosynthesis in Arabidopsis roots," Plant Cell, vol. 17, pp. 1090-1104, 2005.

[5] N. Alami and M. Shovitri, "Marine Yeast sebagai Biofertlizer Potensial," Surabaya.

[6] T. Lasmini and E. S. Soetarto, "Khamir penghasil indole-3-acetic acid dari rhizosfer anggrek tanah Pcteilis susannae (L.) Rafin," Biogenesis, vol. 2, no. 1, pp. 56-62, 2014.

[7] S. A. Gordon and R. . Weber, "Colorimetric estimation of indole acetic acid," Plant Physiol, vol. 26, pp. 192-195, 1951.

[8] D. P. Singh and S. K. Dwivedi, Environmental Microbiology and Biotechnology. New Delhi: New Age International Publishers, 2004.

[9] T. K. Dewi, E. S. Arum, H. Iamuddi, and S. Antonius, "Karakterisasi mikroba perakaran (PGPR) agen penting pendukung pupuk organik hayati," in PROS SEM NAS MASY BIODIV INDON, 2015, pp. 289-295.

[10] S. Spaepen, J. Vanderleyden, and R. Remans, "Indole- 3-acetic Acid in Microbial and Microorganism Plant Signaling," FEMS Microbiol. Lett., vol. 31, pp. 425-448, 2007.

[11] A. Kamnev, A. G. Shchelochkov, P. Tarantillis, M. G. Polissiou, and Y. D. Perfiliev, "Complexation of Indole-3-acetic Acid with Iron(III): Influence of Coordination on the $\pi$-Electronic System of the Ligand," Monatshefte für Chemie, vol. 132, pp. 675-681, 2001.

[12] A. Underwood, Analisis Kimia Kuantitatif, 6th ed. Jakarta: Erlangga, 1990.

[13] S. F. Fu, J. Y. Wei, H. W. Chen, Y. Y. Liu, H. Y. Lu, and J. Y. Chou, "Indole-3-Acetic Acid: A Widespread Physiological Code in Interactions of Fungi with Other Organisms," 2015.

[14] R. P. Rao, A. Hunter, O. Kashpur, and J. Normanly, "Aberrant Synthesis of Indole-3-Acetic Acid in Saccharomyces cerevisiae Triggers Morphogenic Transition, a Virulence Trait of Pathogenic Fungi," Genet. Soc. Am., vol. 185, pp. 211-220, 2010.

[15] P. Nutaratat, N. Srisuk, P. Arunrattiyakorn, and S. Limtong, "Indole-3-acetic acid biosynthetic pathways in the basidiomycetous yeast Rhodosporidium paludigenum," Arch Microbiol, vol. 198, no. 5, pp. 429-437, 2016.

[16] A. S. de A. Scarcella, R. B. Junior, R. G. Bastos, and M. M. R. Magri, "Affect Drastically Indole Acetid Acid Production Of Plant Growth Promoting Yeasts," Brazilian J. Chem. Eng., vol. 34, no. 2, pp. 429-438, 2017.

[17] P. Buzzini, M. A. Lachance, and A. Yurkov, Yeasts in Natural Ecosystems: Diversity. Switzerland: Springer, 2011.

[18] P. Sun, W. Fang, L. Shin, J. Wei, S. Fu, and J. Chou, "Indole-3acetid acid-producing yeasts in the phyllosphere of the carnivorous plant Drosera indica L," PLoS One, vol. 9, no. 12, p. e114196, 2014.

[19] S. Spaepen and J. Vanderleyden, Auxin and Plant Microbe Interaction. Belgium: Cold Spring Harbor Laboratory Press, 2011.

[20] E. Nüske et al., "Filament Formation By The Translation Factor eIF2B Regulates Protein Synthesis In Starved Cells," 2018. [Online]. Available: http://dx.doi.org/10.1101/467829.

[21] N. Dufour and R. P. Rao, "Secondary Metabolites and Other Small Molecules as Intercellular Pathogenic Signals," FEMS Microbiol Lett, vol. 314, pp. 10-17, 2011.

[22] Q. J. Shen et al., "Filamentation of Metabolic Enzymes in Saccharomyces cerevisiae," J. Genet. Genomics, vol. 43, pp. 39340, 2016. 